\title{
Geophysical survey at Talos Dome, East Antarctica: the search for a new deep-drilling site
}

\author{
Massimo FREZZOTTI, ${ }^{1}$ Gabriele BITELLI, ${ }^{2}$ Paola DE MICHELIS, ${ }^{3}$ Alberto DEPONTI, ${ }^{4}$ \\ Alessandro FORIERI, ${ }^{5,}{ }^{6}$ Stefano GANDOLFI, ${ }^{2}$ Valter MAGGI, ${ }^{4}$ Francesco MANCINI, ${ }^{2}$ \\ Frédérique REMY, ${ }^{7}$ Ignazio E. TABACCO, ${ }^{5}$ Stefano URBINI, ${ }^{3}$ Luca VITTUARI, ${ }^{2}$ \\ Achille ZIRIZZOTTL ${ }^{3}$ \\ ${ }^{1}$ ENEA, Centro Ricerche Casaccia, P.O. Box 2400, I-00100 Rome, Italy \\ E-mail: frezzotti@casaccia.enea.it \\ ${ }^{2}$ DISTART, University of Bologna, Viale Risorgimento 2, I-40136 Bologna, Italy \\ ${ }^{3}$ National Institute of Geophysics and Vulcanology (INGV), Via de Vigna Murata, I-00143 Rome, Italy \\ ${ }^{4}$ Department of Environmental Sciences, University of Milano-Bicocca, Piazza della Scienza 1, I-20126 Milan, Italy \\ ${ }^{5}$ Department of Earth Sciences, University of Milan, Via Cicognara 7, I-20129 Milan, Italy \\ ${ }^{6}$ Department of Earth Sciences, University of Siena, Via del Laterino 8, I-53100 Siena, Italy \\ ${ }^{7}$ Legos, CNRS-CNES-UPS, 18 av. Edouard Belin, 31055 Toulouse Cedex, France
}

\begin{abstract}
Talos Dome is an ice dome on the edge of the East Antarctic plateau; because accumulation is higher here than in other domes of East Antarctica, the ice preserves a good geochemical and palaeoclimatic record. A new map of the Talos Dome area locates the dome summit using the global

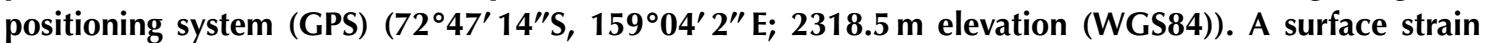
network of nine stakes was measured using GPS. Data indicate that the stake closest to the summit moves south-southeast at a few $\mathrm{cm} \mathrm{a}^{-1}$. The other stakes, located $8 \mathrm{~km}$ away, move up to $0.33 \mathrm{~m} \mathrm{a}^{-1}$. Airborne radar measurements indicate that the bedrock at the Talos Dome summit is about $400 \mathrm{~m}$ in elevation, and that it is covered by about $1900 \mathrm{~m}$ of ice. Snow radar and GPS surveys show that internal layering is continuous and horizontal in the summit area (15 $\mathrm{km}$ radius). The depth distribution analysis of snow radar layers reveals that accumulation decreases downwind of the dome (north-northeast) and increases upwind (south-southwest). The palaeomorphology of the dome has changed during the past 500 years, probably due to variation in spatial distribution of snow accumulation, driven by wind sublimation. In order to calculate a preliminary age vs depth profile for Talos Dome, a simple onedimensional steady-state model was formulated. This model predicts that the ice $100 \mathrm{~m}$ above the bedrock may cover one glacial-interglacial period.
\end{abstract}

\section{INTRODUCTION}

Ice cores provide seasonal- to millennial-res olution records of climate. Isotope and chemical variations in the deposited snow, and gases within trapped bubbles provide proxy records for many aspects of the palaeoenvironment, including temperature, snow accumulation rates, moisture sources, atmospheric dust loading, greenhouse-gas concentrations and bioproductivity. The records from inland East and West Antarctica (Dome C, Dome Fuji, Dome B, Vostok and Byrd) and from an eastern coastal site (Law Dome) are very similar and show a deglacial pattern very different from that registered in Greenland cores (GRIP and GISP2). In contrast, the records from Taylor Dome and Siple Dome, two near-coastal sites in the Ross Sea sector, show Greenland-like features indicative of climate change synchronous with the North Atlantic (Morgan and others, 2002; Watanabe and others, 2003; and references therein). The synchrony or asynchrony of climate change during the Last Glacial Transition in Antarctica and Greenland, and within Antarctica, is a crucial test for theories and models regarding the causes of rapid climate change. High-resolution Holocene climate and environmental records of the Ross Sea area are needed to characterize interglacial variability and understand the significance of modern changes. Since the high inland plateau of the Antarctic ice sheet is isolated by distance from local sources of aerosol, chemical-isotopic signals in ice cores from this area are considered to reflect the global environment. Ice cores from the margin of the continent can provide a better record of the deglaciation process and of environmental conditions in coastal areas and the surrounding ocean.

There are currently only a few ice cores from coastal sites that record Holocene and recent climate change, or the retreat of the ice sheet since the Last Glacial Maximum (LGM). An accurate knowledge of deglaciation in Antarctica and of environmental conditions (sea-ice extension, snow accumulation, temperature, etc.) since the LGM is important for understanding the past, present and future behaviour of Antarctic mass balance, and hence the cause of Holocene and 20th-century sea-level rises. The investigation of Antarctic deglaciation over millennial time-scales, from the LGM through the Holocene to the present, with decadal resolution, should reveal the relative influence of sea-level change (from Northern Hemisphere deglaciation), and changes in the Antarctic climate (the ice accumulation regime) and Southern Ocean (sea-ice extension, El NiñoSouthern Oscillation) recorded in ice-core records. Defining the natural variability of climate under Holocene conditions, more or less similar to present conditions, requires highresolution records over a large area.

Stenni and others (2002) pointed out that the ice at Talos 


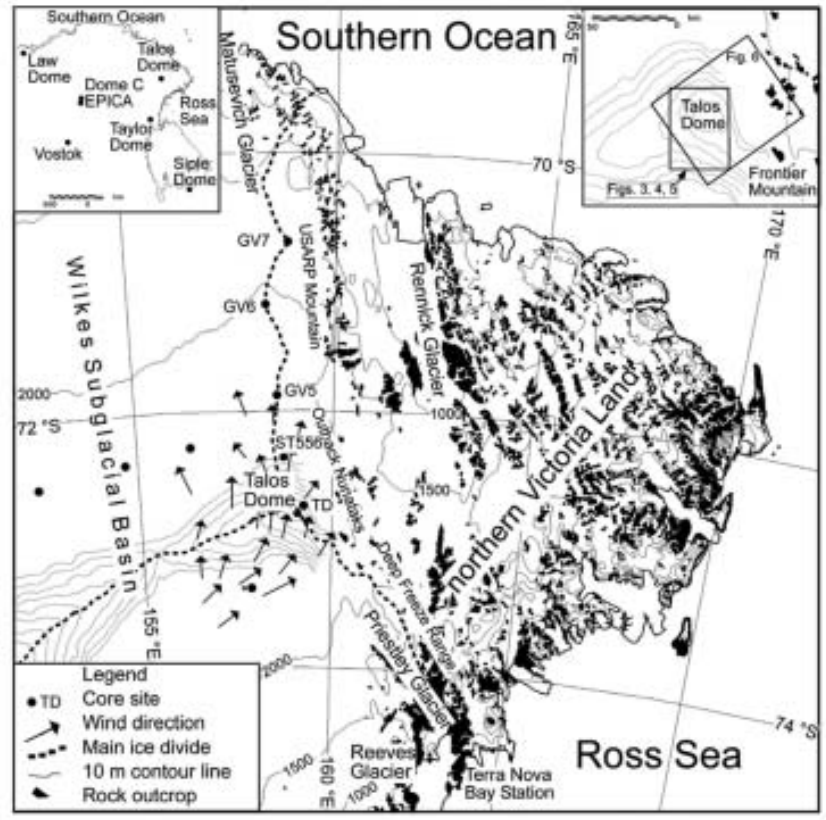

Fig. 1. Schematic map of Talos Dome drainage (contour every $500 \mathrm{~m}$; contour every $10 \mathrm{~m}$ in Talos Dome area) from digital elevation model provided by Rémy and others (1999).

Dome preserves a good geochemical and palaeoclimatic record, because accumulation is higher than at other domes in East Antarctica. As part of the International TransAntarctic Scientific Expedition (ITASE) project, two traverse surveys were carried out in the Talos Dome area (Frezzotti and others, 1998, 2003). Research aimed to better understand the latitudinal (north-south) and longitudinal (eastwest) environmental gradient along two east-west (Talos Dome-D66) and north-south (GV7-Talos Dome-Taylor Dome) transects, while documenting climatic, atmospheric and surface conditions in the Talos Dome area and northern Victoria Land throughout the last 200-1000 years (Fig. 1). The northwestern drainage area of Talos Dome base is mostly below sea level (Wilkes Subglacial Basin). For this reason, this drainage area is more sensitive to climatic and eustatic fluctuations than other sectors of the East Antarctic ice sheet (Warner and Budd, 1998). Research on Talos Dome aimed to characterize the area and find the best location to extract an undisturbed ice core down to the bedrock.

\section{GEOGRAPHICAL AND CLIMATIC CHARACTERISTICS}

Talos Dome is an ice dome on the edge of the East Antarctic plateau (Fig. 1), about $290 \mathrm{~km}$ from the Southern Ocean, $250 \mathrm{~km}$ from the Ross Sea, $275 \mathrm{~km}$ from the Italian station (Mario Zucchelli Station at Terra Nova Bay), $550 \mathrm{~km}$ north of Taylor Dome, $1500 \mathrm{~km}$ northwest of Siple Dome and $1100 \mathrm{~km}$ east of Dome C.

An ice saddle $(2260 \mathrm{~m})$ west of Talos Dome separates the dome from an ice ridge coming from Dome C. Ice flows southeast from this ridge into outlet glaciers (Priestley and Reeves Glaciers), which drain into the Ross Sea, and northwest into Rennick and Matusevich Glaciers, which drain into the Southern Ocean. Another ice divide trends north from Talos Dome, passing behind the USARP Mountain and southeast of the Deep Freeze Range.

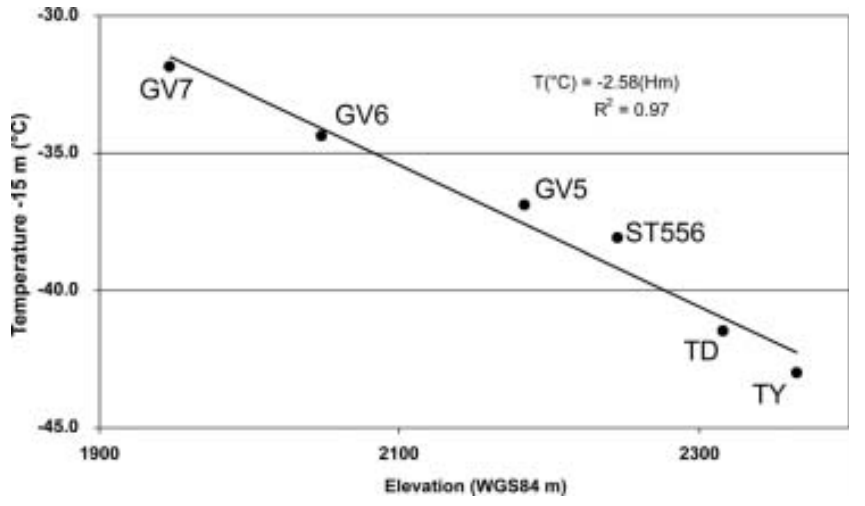

Fig. 2. Temperature at $15 \mathrm{~m}$ depth in firn as a function of ice-sheet elevation. The line shows the linear regression of the data.

The dome features were delineated for the first time in the USGS (1970) Welcome Mountain map, on the basis of the US Victoria Land traverse altimetric profile (Stuart and Heine, 1961). Drewry (1983) delineated and named Talos Dome morphological features (at $73^{\circ} \mathrm{S}, 158^{\circ} \mathrm{E}$ ) with data from the Scott Polar Research Institute (SPRI)-US National Science Foundation (NSF)-Technical University of Denmark (TUD) airborne radio-echo sounding programme (1967-79). European Remote-sensing Satellite-1 (ERS-1) radar altimeter data (Rémy and others, 1999) located the dome at $72^{\circ} 46^{\prime} \mathrm{S}$, $159^{\circ} 04^{\prime} \mathrm{E}$. The new position is $50 \mathrm{~km}$ south of the USGS map position and $42 \mathrm{~km}$ east of the Drewry position.

Six shallow snow-firn cores (two in 1996 and four in $2001 / 02$ ), up to $89 \mathrm{~m}$ deep (TD) were drilled in the Talos Dome area (Stenni and others, 2002; Magand and others, 2005). In areas where there are no meteorological records, the snow temperature measured at 10 or $15 \mathrm{~m}$ depth closely approximates the mean annual 'surface temperature' in dry snow and the mean annual 'screen air temperature' (Loewe, 1970). This assumption is acceptable in areas where maximum temperatures are $<0^{\circ} \mathrm{C}$ during summertime, as in the considered sampling sites. Firn temperature was measured using ten 'Pt $100 \mathrm{ohm}$ at $0^{\circ} \mathrm{C}^{\prime}$ probes after 1524 hour stabilization, at 1, 3, 5, 7, 10, 13, 15, 20, 25 and $30 \mathrm{~m}$ depths (for boreholes deeper than $30 \mathrm{~m}$ ) and at the bottom for 12-15 m boreholes. The tops of the holes were carefully closed with a foam rubber stopper to prevent air from flowing down the hole. Two cores, TD (89 m) and TDC ( $55 \mathrm{~m}$ ), were drilled $5 \mathrm{~km}$ apart close to Talos Dome summit. A temperature of $-41.0^{\circ} \mathrm{C}$ was recorded at $15 \mathrm{~m}$ depth at the TD core during the 1996 expedition (Frezzotti and others, 1998) and of $-41.5^{\circ} \mathrm{C}$ at $15 \mathrm{~m}$ depth at TDC in 2002. Temperature strongly correlates with surface elevation (Fig. 2), and the decrease in temperature with elevation shows a super-adiabatic lapse rate $\left(2.5^{\circ} \mathrm{C}(100 \mathrm{~m})^{-1}\right)$ along the ice divide between Talos Dome and the Southern Ocean coast (GV7). The $-10 \mathrm{~m}$ temperature at Taylor Dome follows the same super-adiabatic lapse rate between GV7 and TD (Fig. 2). These data are quite different from the sub-adiabatic lapse rate $\left(0.5^{\circ} \mathrm{C}(100 \mathrm{~m})^{-1}\right)$ calculated by Stenni and others (2000) using $10 \mathrm{~m}$ core temperatures for the close mountainous regions of Victoria Land, and from the near-dryadiabatic lapse rate (about $1.0^{\circ} \mathrm{C}(100 \mathrm{~m})^{-1}$ ) observed along the traverses from Terra Nova and Dumont d'Urville to Dome C (Frezzotti and Flora, 2002; Magand and others, 2005). The super-adiabatic lapse rate calculated along the 


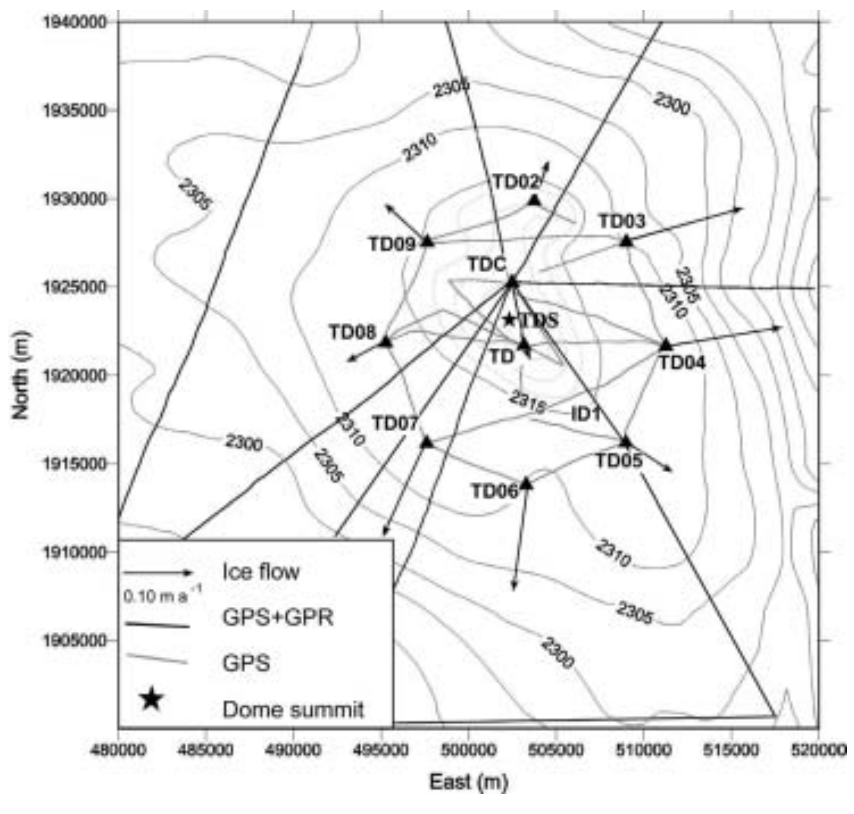

Fig. 3. Detailed Talos Dome map from GPS survey with GPR-GPS profiles, ice velocities and summit position (TDS). Map projection in Universal Transverse Mercator (UTM) (WGS84).

Talos Dome ice divide suggests prevailing calm conditions, with a strong temperature inversion during the winter.

Wind-driven sublimation processes, controlled by surface slope in the wind direction, have a huge impact (up to $85 \%$ of snow precipitation) on surface mass balance and on the reconstruction of past climates based on ice-core data (Frezzotti and others, 2002b, 2004). It is important to consider aeolian processes when selecting optimum sites for ice coring, because slope variations of even a few metres per kilometre have a significant impact on winds and the snow accumulation process (Frezzotti and others, in press). The prevalent wind direction and aeolian morphology at Talos Dome was described on the basis of integrated field observations and remotely sensed data (Frezzotti and others, 2002a; Mancini and Frezzotti, 2003). Aeolian surface microrelief is mostly due to redistribution (sastrugi), with southerly, south-southwesterly and east-southeasterly directions at the dome; the wind blows mainly from the southsouthwest in the windward area and changes direction (south, south-southwest and east-southeast) at the ice divide and in the downwind area (Fig. 1). These observations generally agree with streamline results from the katabatic wind-field model simulation of Parish and Bromwich (1991). Satellite data show that the prevalent winds on the windward side blow from the south and southeast $\left(5-10^{\circ}\right)$; they climb the dome topography and, on the downwind side, blow east-northeast and north along the Rennick Glacier valley $\left(35^{\circ}\right)$ and the north ice divide $\left(5^{\circ}\right)$. Continental-scale simulation of the wind-field surface (Parish and Bromwich, 1991) shows that the Talos Dome area is characterized by constant katabatic winds, with speeds $<6 \mathrm{~m} \mathrm{~s}^{-1}$. Wind speeds $<15 \mathrm{~m} \mathrm{~s}^{-1}$ produce transverse features such as ripples, waves and barchans (depositional features), whereas greater speeds produce longitudinal features such as dunes and sastrugi (Kobayashi and Ishida, 1979). A surface microrelief survey performed in November 1996 identified sastrugi of up to $20 \mathrm{~cm}$. The presence of longitudinal features (sastrugi) indicates that the threshold wind velocity of $15 \mathrm{~m} \mathrm{~s}^{-1}$ is

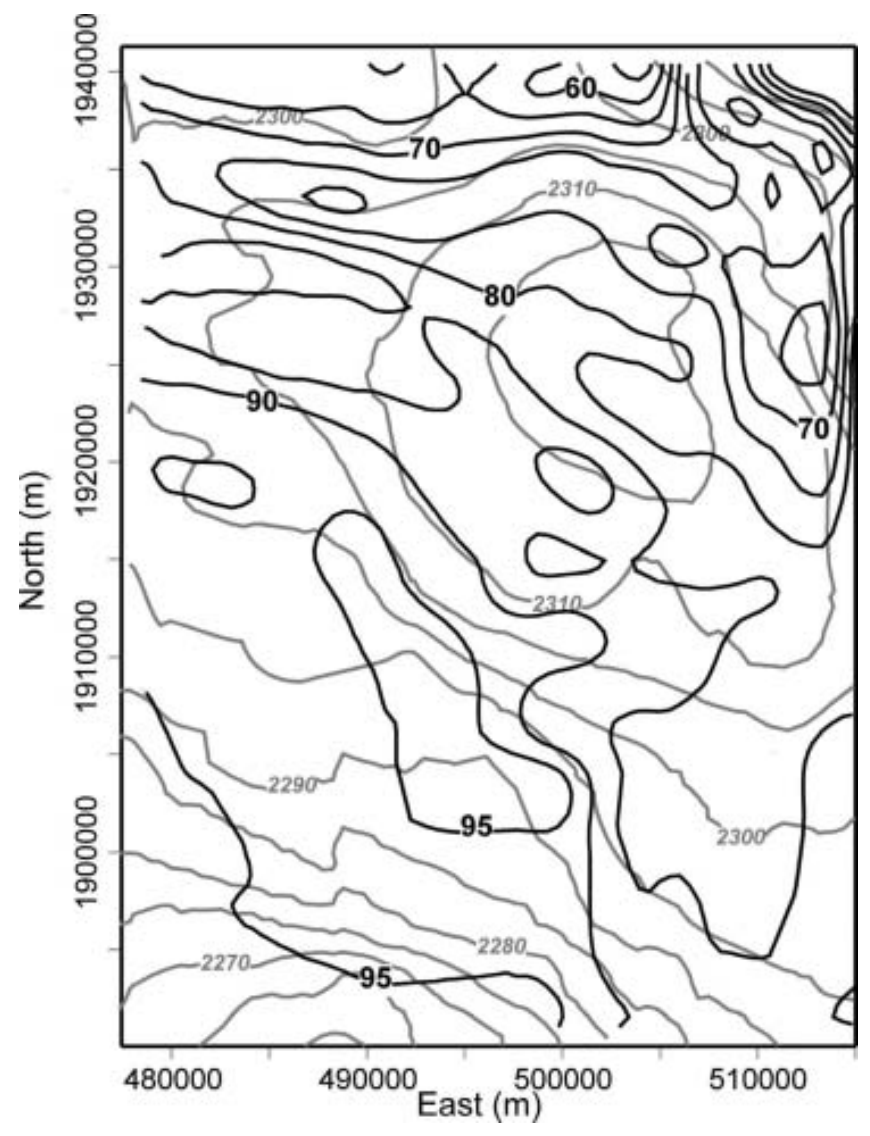

Fig. 4. Snow accumulation map $\left(\mathrm{kg} \mathrm{m}^{-2} \mathrm{a}^{-1}\right)$ by snow radar (third layer, 366 year average) and surface topography (grey line). Map projection in UTM (WGS84).

sometimes exceeded at Talos Dome. The south-southwesterly winds blowing at Talos Dome have a negative gradient of $1-2 \mathrm{~m} \mathrm{~km}^{-1}$ from about $2150 \mathrm{~m}$ up to the summit of the dome $(2318 \mathrm{~m})$; the distance between the lower elevation and the summit is about $100 \mathrm{~km}$. The wind that reaches Talos Dome blows to the north-northeast and forms the blue-ice areas of Roberts Butte $(2828 \mathrm{~m})$, Miller Butte $(2610 \mathrm{~m})$ and Frontier Mountain (2804 m), $40 \mathrm{~km}$ away (Fig. 1). The Frontier Mountain blue-ice area is characterized by an ice mean sublimation rate of $65 \mathrm{~mm} \mathrm{a}^{-1}$, with winds capable of moving stones of up to $200 \mathrm{~g}$ along the flattish surface at speeds of 1-10 $\mathrm{m} \mathrm{a}^{-1}$ (Folco and others, 2002).

\section{SURFACE TOPOGRAPHY AND ACCUMULATION-RATE VARIABILITY}

Within a $20 \mathrm{~km}$ radius of the summit, $300 \mathrm{~km}$ of snow radar or ground-penetrating radar (GPR) and $450 \mathrm{~km}$ of kinematic global positioning system (GPS) surveys were performed in order to link core sites and obtain detailed information on the spatial variability of snow accumulation and topography (Figs 3 and 4).

GPR data acquisition was performed with a Geophysical Survey Systems Inc. (GSSI) Sir10B unit equipped with one monostatic antenna with a central frequency of $200 \mathrm{MHz}$. The GPR unit was mounted inside the vehicle (Pisten Bully 330D) cabin together with a geodetic GPS instrument, while the antenna was pulled on a small wooden sledge. GPR principal acquisition parameters were $750 \mathrm{~ns}$ for the vertical investigation range $(60-70 \mathrm{~m})$ and 1 scan s$^{-1}$ for the 

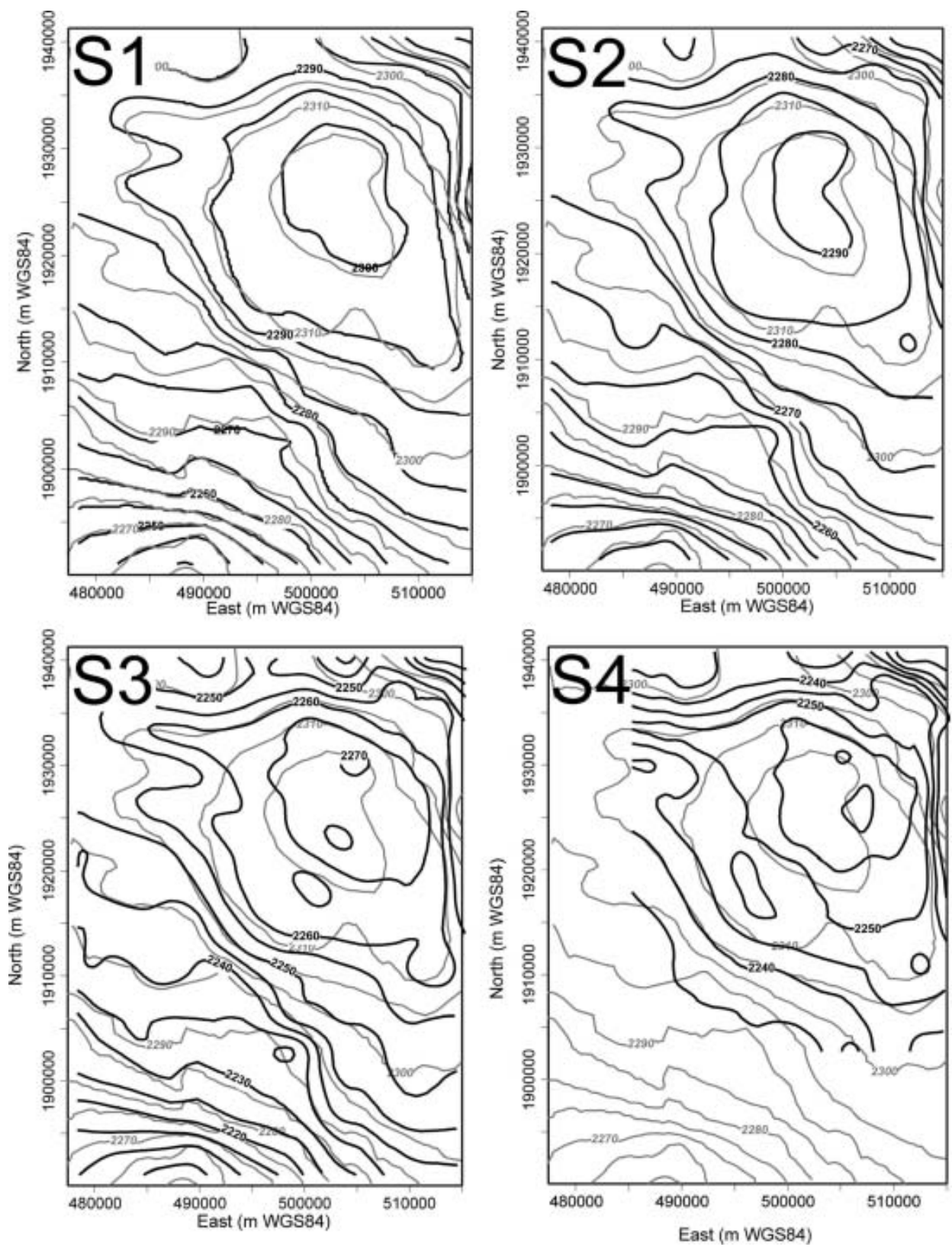

Fig. 5. Surface topography (grey) and palaeotopography (black) map of Talos Dome area. S1: layer 1 (AD 1925); S2: layer 2 (AD 1835); S3: layer 3 (AD 1635); S4: layer 4 (AD 1525). Map projection in UTM (WGS84).

acquisition rate. Geodetic Trimble 4000 SSI and 5700 dualfrequency receivers were used for kinematic surveys, using high sampling rates (GPS sample rate at $1 \mathrm{~s}$ ) to allow a detailed survey of altimetric profiles. Vehicle, and thus antenna, speed oscillated from about 12 to $16 \mathrm{~km} \mathrm{~h}^{-1}$, equivalent to one scan every $3-4 \mathrm{~m}$.

GPS data processing was performed using GeoGenius 2000 (TerraSat $\mathrm{GmbH}$ ) software, which can process both static and kinematic GPS data using precise orbits and models for phase centre variations of GPS geodetic antennae. The master station was installed at the TDC site (Fig. 3), and the absolute position of this site was measured using the permanent GPS station at Terra Nova Bay. The accuracy of the altimetric profile is mainly determined by the distance between master and rover and by the penetration of the vehicle into the snow between one passage and the other. The reliability of the kinematic survey was tested analyzing the difference in height at intersections between different profiles, or in portions of profiles covered twice; heights were found to vary from $5 \mathrm{~cm}$ to a maximum of $20 \mathrm{~cm}$. A preliminary data analysis was performed in the field; by identifying the culmination, it was possible to increase the density of surveyed points in the summit area. Based on this data, a new plano-altimetric map of the Talos Dome area (Fig. 3) was drawn up for an area of about $200 \mathrm{~km}^{2}$; the dome summit (TDS $\left(72^{\circ} 47^{\prime} 17.14^{\prime \prime} \mathrm{S}\right.$, $159^{\circ} 04^{\prime} 21.63^{\prime \prime} \mathrm{E} ; 2318.5 \mathrm{~m}$ above the World Geodetic System 1984 (WGS84) ellipsoid)) is located about $1.5 \mathrm{~km}$ north of the previous ERS-1 position (TD in Fig. 3). Using the crossover results and the spatial distribution of GPS profiles, the accuracy associated with the location of the summit is about $30 \mathrm{~m}$ in the south-north direction, $100 \mathrm{~m}$ in the eastwest direction and $<20 \mathrm{~cm}$ in elevation.

GPR surveys along continuous profiles provide detailed information on spatial variability in snow accumulation (Richardson and others, 1997; Richardson and Holmlund, 
1999; Urbini and others, 2001). For electromagnetic wave speed calculation, the depth-density relation for the snowpack was established using the density profile of three firn-ice cores (26-89 $\mathrm{m}$ deep) and two trenches $(2.5 \mathrm{~m}$ deep). Density data inserted in second-order polynomial functions yielded a determination coefficient $\left(R^{2}\right)$ of $>0.97$. Urbini and others (2001) describe the GPR methods in detail. Like other authors (e.g. Richardson and others, 1997; Vaughan and others, 1999; Frezzotti and others, in press), we assume that layers that produced a strong radar reflection are isochronous. We did not take into account layer thinning due to vertical strain, since the ratio of the layer depth $(70 \mathrm{~m})$ to the entire ice thickness $(1500-2000 \mathrm{~m})$ is $<5 \%$ and thus negligible (Stenni and others, 2002). The layer depths measured at intersecting points show good agreement. Crossover point analysis shows that depth values are in good agreement; we found an average discrepancy of $15 \mathrm{~cm}$, with a maximum value of $35 \mathrm{~cm}$.

Analysis of snow radar and GPS data shows that internal layering is continuous and horizontal up to $15 \mathrm{~km}$ from the dome. Undulated internal layering is present in the steeper eastern areas (Fig. 4). Analysis of snow radar in the summit area and along the ice divide revealed no distortion of isochrons due to ice-flow dynamics.

We were able to trace four internal layers continuously across all profiles. The depth of these layers and the ellipsoidal heights were derived from GPS-GPR data and used to construct maps of isochronous surfaces. In the process, the three-dimensional surfacial structure $(70 \mathrm{~m})$ of the dome was defined (Fig. 5). Ages were assigned to our isochronous maps from the stratigraphic correlation with the firn-ice core drilled in 1996. The TD core $(89 \mathrm{~m})$ was dated using seasonal variations in $\mathrm{nssSO}_{4}{ }^{2-}$ concentrations, coupled with the identification of tritium marker levels (1965-66) and $\mathrm{nssSO}_{4}{ }^{2-}$ spikes from the most important past volcanic events (Stenni and others, 2002). According to the depth-age function and depth of layers at TD, layer 1 $(14.8 \mathrm{~m})$ dates to $\mathrm{AD} 1920$, layer $2(26.7 \mathrm{~m})$ to $\mathrm{AD} 1835$, layer $3(49.3 \mathrm{~m})$ to $\mathrm{AD} 1635$, and the lowest traceable layer, layer 4 $(61.2 \mathrm{~m})$, to $\mathrm{AD} 1525$.

Mean, minimum and maximum depth, and standard deviation were computed for the deeper, continuous layer (the third). Data from the four layers were mapped using kriging interpolation (linear semivariogram, nugget equal to 0.003), and an elevation model was created for each layer. The four maps provide information about the areal distribution of accumulation and the palaeomorphology of the dome of each layer (Fig. 5). The overall pattern is the same in all the layer maps. The statistical analysis of third-layer profiles shows (Fig. 4):

the highest standard deviation (from $14 \%$ to about $30 \%$ ) and shallowest depth $(47.3 \mathrm{~m})$ in the northern part of the dome;

an intermediate standard deviation (8-16\%) and the greatest depth $(55.6 \mathrm{~m})$ in the southern sector;

the lowest standard deviation (1.6-6.6\%) along the southeastern ice divide.

Analysis of the depth distribution of layers shows that accumulation decreases downwind of the Dome (northnortheast), and that accumulation is higher in the southwestern sector. GPR profiles along the traverse (GV7-GV6GV5-TD-M3-31Dpt), in agreement with snow accumu-

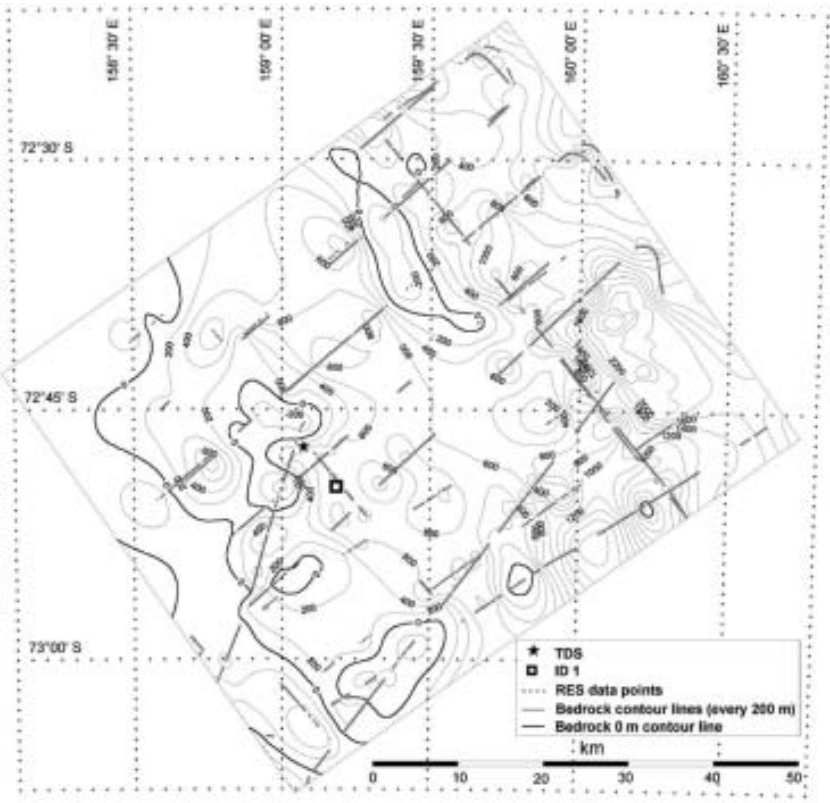

Fig. 6. Bedrock elevation in Talos Dome area. TDS: summit of dome; ID1: ice divide. See Figure 1 for area location.

lation data from firn cores (Magand and others, 2005), show a decrease in snow accumulation in the dome and leeward areas, and a marked increase in snow accumulation from about $40 \mathrm{~km}$ north-northeast of Talos Dome up to the Southern Ocean coast.

\section{BEDROCK TOPOGRAPHY AND ICE THICKNESS}

Airborne radar surveys were conducted in the Talos Dome area in 1997, 1999 and 2001. The data were acquired by means of a radar system operating at $60 \mathrm{MHz}$ frequency linked to a GPS (INGV-IT digital radar). Ice thickness was calculated using a constant velocity of $168 \mathrm{~m} \mathrm{\mu s}^{-1}$ (Tabacco and others, 1998, 2002). Airborne radar measurements were carried out on a $72 \mathrm{~km} \times 60 \mathrm{~km}$ rectangular grid $\left(4320 \mathrm{~km}^{2}\right)$ comprising the entire dome area and two of the Outback Nunataks, for a total length of about $1750 \mathrm{~km}$. The spacing between flight-lines is about $10 \mathrm{~km}$ in the east-west direction and about $25 \mathrm{~km}$ in the north-south direction (Fig. 6). Radar data are not homogeneous, because radar systems with different characteristics were used (cf. Tabacco and others, 1998, 2002). The main radar-systems improvements between 1996 and 2001 concern the total range time (which increased from $51.2 \mu \mathrm{m}$ to $64 \mu \mathrm{m}$ ), the number of samples for each radar track (enhanced from 1024 to 1280 samples) and the number of acquired tracks per second (raised from 1 track s$^{-1}$ to 10 tracks s$^{-1}$ ). To obtain a homogeneous dataset, all data were processed following the same criteria and cross-checked. Crossover point analysis shows that ice-thickness values are in good agreement. Indeed, $51 \%$ of cross-points are at a distance of $<200 \mathrm{~m}$, and about $50 \%$ have an ice-thickness difference of $<40 \mathrm{~m}$ (A. Forieri and others, unpublished information). In the area there are only five ice-thickness measurements available from the BEDMAP database (Lythe and others, 2000). These data are extracted from a SPRI radar survey done in 1972 (Drewry, 1983) and are located about $30 \mathrm{~km}$ north of the Talos Dome summit along a west-east flight-line at 
about $72.6^{\circ} \mathrm{S}$. These bedrock elevations and ice thickness are quite different from our measurements, but this could be due to the large error $(>3 \mathrm{~km})$ in the SPRI data location.

Difficulties arose in the analysis of radar echoes. Results are not as good as expected, and bottom reflections were sometimes lost; about 35\% of data could not be used due to the lack of return echoes from the bedrock (Fig. 6). The internal layering below the dome is detectable in some legs up to 1400-1500 m; reflecting horizons are irregular and discontinuous.

The weakness of reflections from the base of the ice sheet does not allow wet and dry conditions at the ice-bedrock interface to be distinguished. Preliminary results indicate that the bedrock of the Talos Dome summit (TDS) is about $400 \mathrm{~m}$ in elevation (WGS84), and that it is covered by about $1900 \mathrm{~m}$ of ice (Figs 3 and 6). The dome summit is situated above a sloped bedrock, but $5-6 \mathrm{~km}$ away there is a relatively flat bedrock along the southeast ice divide (ID1; $72^{\circ} 49^{\prime} 40^{\prime \prime} \mathrm{S}, 159^{\circ} 11^{\prime} 00^{\prime \prime} \mathrm{E}$ ), where the bedrock is about $750 \mathrm{~m}$ (WGS84) in elevation and covered by $1550 \mathrm{~m}$ of ice. About $30 \mathrm{~km}$ to the northeast, a sharp northwest-southeast ridge borders a flat area.

\section{ICE VELOCITY AND SURFACE ELEVATION CHANGE}

The surface strain network consisted of nine stakes geometrically located at $8 \mathrm{~km}$ from the centre of the topographic dome (TD) defined by ERS-1 radar altimeter data provided by Rémy and others (1999). The network was established in 1996 and measured using GPS in November 1996, December 1998 and January 2002. The TD01 reference pole (located close to the 1996 TD core; Fig. 3) was positioned with static GPS using the Terra Nova Bay permanent GPS station ( $275 \mathrm{~km}$ away) as the only fixed station. We were thus able to minimize geodynamic effects in our data. Several 24 hour GPS sessions were acquired in 1996 and 2002, and 10 hour sessions were acquired in 1998. GPS data were processed with Bernese v. 4.2 software using precise orbits. Strain network data were acquired using static GPS, with sessions of at least 3 hours for baselines of up to $16 \mathrm{~km}$. Surface velocities of stakes relative to the reference pole TD01 were determined through repeat measurements. The estimated uncertainty in velocity measurements is $0.02 \mathrm{ma}^{-1}$ for the horizontal component of ice flow at the surface, and $0.03 \mathrm{~m} \mathrm{a}^{-1}$ for the vertical component. The observed movement over the years was corrected for the length of the measurement period in order to obtain annual movement over 365 days (Table 1).

Surface velocities are perpendicular to the surface contour lines; site TD01 (TD in Fig. 3) moves southsoutheast at a rate of $0.04 \mathrm{~m} \mathrm{a}^{-1}$, and the other stakes move with radial velocities of $0.11-0.33 \mathrm{~m} \mathrm{a}^{-1}$. The higher horizontal velocities are recorded in the steeper south-southwest (TD06 and TD07) and east-northeast (TD04 and TD03) slopes. Excluding TD01, the lowest horizontal velocities are recorded to the north (TD02), northwest (TD09) and west (TD08), about 6-7 km from the summit, and to the southeast (TD05), about $9.5 \mathrm{~km}$ from the dome summit along the southeast ice divide (Fig. 3).

The absolute elevation of the stakes, measured by GPS, decreased with an average value of $0.21 \mathrm{~m} \mathrm{a}^{-1}$ and standard deviation of $0.02 \mathrm{ma}^{-1}$ during the 1996-2002 period. An average snow accumulation value of $1.08 \mathrm{~m}$, with a standard deviation of $0.19 \mathrm{~m}$, and a surface mass balance of $83 \mathrm{~kg} \mathrm{~m}^{-2} \mathrm{a}^{-1}$, with a standard deviation of $15 \mathrm{~kg} \mathrm{~m}^{-2} \mathrm{a}^{-1}$, were measured during the 1996-2002 period. The accumulation value is qualitatively comparable with that ( 779 years, $80.5 \mathrm{~kg} \mathrm{~m}^{2} \mathrm{a}^{-1}$ ) determined on the basis of longterm core marker analysis (Stenni and others, 2002). The decrease in elevation with respect to the snow accumulation value indicates that the stakes were anchored to the bottom. Snow accumulation values derived from stakes and from vertical velocities are in good agreement with higher values in the west-south sector and lower values in the northeast-east sector (Figs 3 and 4). Intermediate values are present close to the summit (TD01) and along the southeast ice divide (TD05). The absolute elevation of snow surfaces shows an irregular pattern due to the presence of sastrugi.

\section{AGE VS DEPTH MODELLING}

For a preliminary estimate of time-scales, we used the mean accumulation rate $\left(80.5 \mathrm{~kg} \mathrm{~m}^{-2} \mathrm{a}^{-1}\right)$ and firn-ice density profile $(89 \mathrm{~m})$ obtained from 1996 core sampling (Stenni and others, 2002). The close-off value of $830 \mathrm{~kg} \mathrm{~m}^{-3}$ was measured at about $66 \mathrm{~m}$ depth (AD 1460, $\Delta$ ages about 535 years), and a density of $930.77 \mathrm{~kg} \mathrm{~m}^{-3}$ was recorded at $89 \mathrm{~m}$.

The age profile along a vertical line was evaluated by:

$$
t(z)=\tau \int_{z}^{H} \frac{d \xi}{\lambda(\xi)}
$$

where $z$ is the vertical coordinate (the origin of the $z$ axis is located on the bedrock), $H$ is the surface elevation, $\tau=1$ year and $\lambda(z)$ is the vertical annual-layer thickness profile (Reeh, 1989; Deponti and Maggi, 2003). The proposed model assumes a variable density in the upper $89 \mathrm{~m}$, and a constant density of $930.77 \mathrm{~kg} \mathrm{~m}^{-3}$ in the rest of the ice profile. The density profile in the upper part of the borehole is represented by a quadratic polynomial equation obtained by interpolating measurements along an $89 \mathrm{~m}$ long borehole drilled at Talos Dome in 1996:

$$
\rho(z)= \begin{cases}A\left(H-z_{\mathrm{C}}\right)^{2}+B\left(H-z_{\mathrm{C}}\right)+C & z \in\left[0, z_{\mathrm{C}}\right) \\ A(H-z)^{2}+B(H-z)+C & z \in\left[z_{\mathrm{C}}, H\right]\end{cases}
$$

where $A=-3 \times 10^{-5}, B=8.4 \times 10^{-3}, C=0.4208$ and $Z_{\mathrm{C}}=H-89$. The ice mass is characterized by a non-null vertical strain rate; nevertheless, the strain rate must decrease near the bedrock (Schwander and others, 2001), becoming null if the ice is frozen to a horizontal bed (Reeh, 1989). The present bottom ice temperature was estimated considering a geothermal heat flux of $40-80 \mathrm{~mW} \mathrm{~m}^{-2}$; in all simulations the basal temperature was well below the pressure-melting point. The model does not therefore take into account melting/refreezing at the base. The normalized vertical strain rate is represented by:

$$
e(\xi)=1-\mathrm{e}^{-12 \xi}
$$

where $\xi=z / H$. The shape of the proposed function agrees with those proposed by Dansgaard and Johnsen (1969) and Reeh (1989). The shape function for both the vertical velocity and annual-layer thickness was obtained by integrating Equation (3) and normalizing it:

$$
\Psi(\xi)=\frac{12}{11+\mathrm{e}^{-12}}\left[\xi+\mathrm{e}^{-12 \xi}-1\right] .
$$


Table 1. Position (2002) of the reference pole at Talos Dome, shifting and annual movement

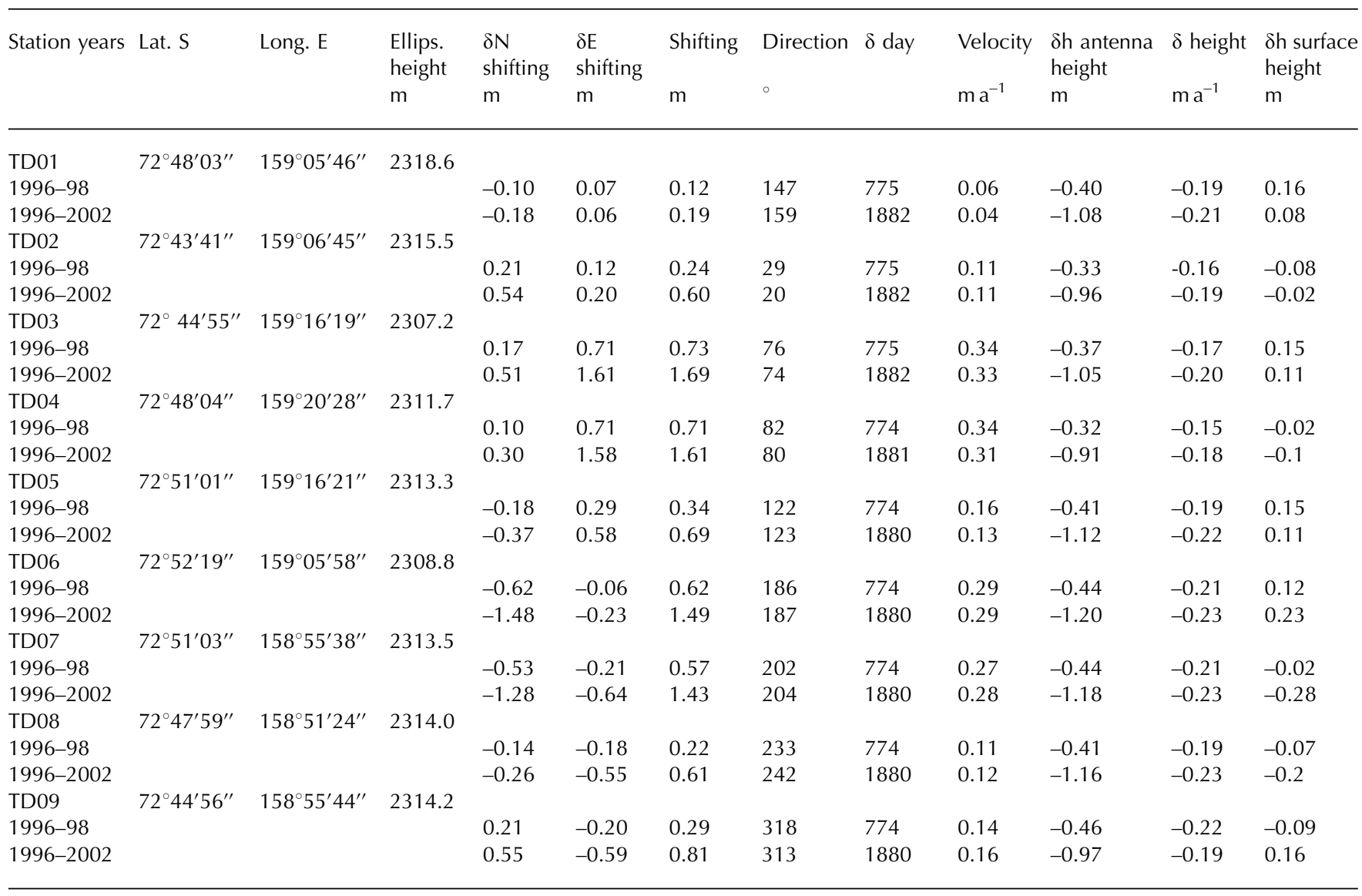

Assuming a steady state, the annual-layer thickness and vertical velocity are:

$$
\lambda(\xi)=-\tau w(\xi)=\tau a \Psi(\xi),
$$

where $a$ is the accumulation rate expressed in $m$ w.e. $a^{-1}$ (Robin, 1983). Stenni and others (2002) pointed out similarities and differences in the $\delta \mathrm{D}$ records of Dome $\mathrm{C}$ EPICA and TD, on the one hand, and Taylor Dome and South Pole, on the other. The similarities between TD-Dome $C$ and Taylor Dome-South Pole could be correlated to different distribution of storm tracks and moisture origins. The eightcentury accumulation value was used for the Holocene period and for all warm stages. Half of the current value was used for the Holocene/Last Glacial Transition, whereas a third of the current value was used for all cold stages. The transitions between the various stages were inferred from the isotopic curves from Vostok (Petit and others, 1999 ) and the upper part of Dome C (Delmonte and others, 2002).

Water equivalent coordinates were used to calculate the age profile. The age profile in water equivalents was obtained by combining Equations (1), (4) and (5) and integrating the resulting equation. Integration was carried out numerically by the trapezoid method. The age profile for the real geometry of Talos Dome was calculated using the density profile represented in Equation (2) and two thicknesses: 1900 and $1550 \mathrm{~m}$ (Fig. 7).

The sensitivity of the model to the accumulation rate was evaluated by varying the accumulation values for all stages $( \pm 30 \%)$

\section{DISCUSSION}

Surface contour lines are elliptical and elongated in a northwest-southeast direction; the northwest and northeast slopes are steeper. The elongation direction of the dome is perpendicular to the prevalent wind direction and parallel to the outcropping Outback Nunataks and to the sharp northwest-southeast ridge in the bedrock. Surface and buried velocities are coherent with the topographic summit and the accumulation pattern, but the flow centre at depth may not be located beneath the surface flow centre. Identification of the flow centre at depth requires precise knowledge of bedrock topography (Van der Veen and Whillans, 1992), which is not yet available (Fig. 6).

We were able to detect the palaeomorphology of the dome by analyzing internal layers across the dome using GPR-GPS (Fig. 5). Variation of firn thickness in internal layers is mainly due to changes in the spatial distribution of accumulation over time. Analysis of the palaeomorphology of the four layers is coherent and indicates that between layer 4 (AD 1525) and layer 2 (AD 1835) the dimensions and shape of the dome have changed, with a reduction in the north-northeastern part. The variation of palaeomorphology change is opposite to that of ice flow. It is in agreement with the direction of prevailing winds (south-southwest to northnortheast) and with the decrease in accumulation patterns surveyed in the north-northeast area. Frezzotti and others (2004) pointed out that wind-driven sublimation processes, controlled by surface slope in the prevalent wind direction, have a huge impact on surface mass balance. The south- 


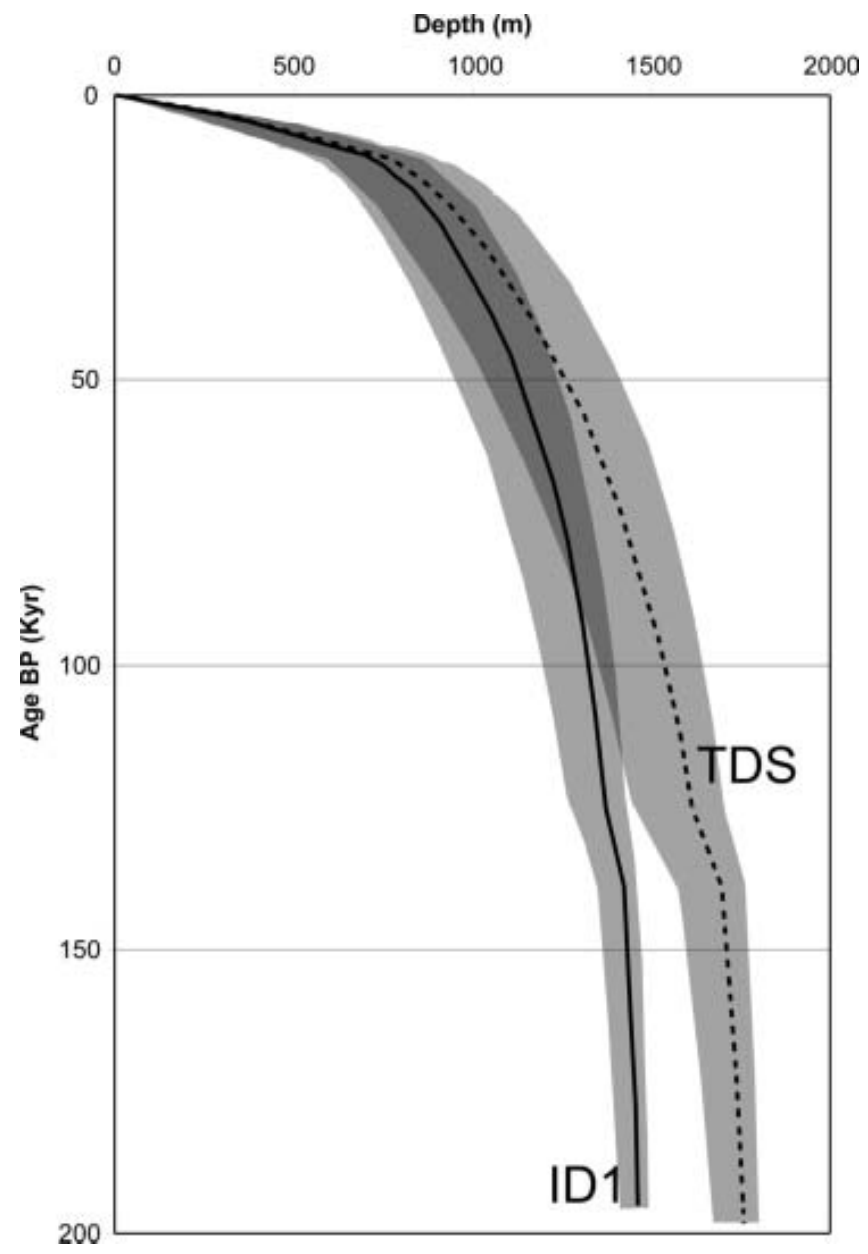

Fig. 7. Age-depth profile for the $1550 \mathrm{~m}$ (ID1) and $1900 \mathrm{~m}$ (TDS) simulations (solid lines). Grey area represents the upper and lower bound of the sensitivity band with respect to the accumulation rate history $( \pm 30 \%)$.

southwesterly wind at Talos Dome blows uphill with a gradient of $1-2 \mathrm{~m} \mathrm{~km}^{-1}$ for $100 \mathrm{~km}$. The higher accumulation in the south-southwest sector could be correlated with reduced wind velocities in this sector due to the positive slope gradient and the reduction in wind-driven sublimation, whereas the accumulation decrease in the downwind sector is due to an increase in wind-driven sublimation controlled by the increase in surface slope in the Rennick Basin. The $\delta \mathrm{D}$ and snow accumulation rate recorded for the TD core shows a cooler condition and snow accumulation decrease during part of the Little Ice Age followed by an increment of about $11 \%$ in accumulation during the 20th century (Stenni and others, 2002). An increase in snow precipitation coupled with an increase in temperature and wind could increase the snow accumulation in the less windy area, whereas it could determine a decrease in snow accumulation in the windy areas.

Ice divides and domes are known to migrate because of the interaction between ice load, bedrock, surface elevation and accumulation. Thus, there is no guarantee that an ice core drilled at the present summit of a dome will sample ice from the ancient ice divide. Glacial geology surveys and reconstructions indicate that the migration of the grounding line induced by sea-level changes is the main factor governing the evolution of coastal areas of the East Antarctic ice sheet during the LGM. On the other hand, the ice cover in the central part of East Antarctica was generally thinner (by about 150-200 m) than today, and its thickness varied mainly according to accumulation fluctuations (Ritz and others, 2001; Huybrechts, 2002). The surface elevation of the Talos Dome drainage area during the LGM, present in the lower section of the glacier, rose to $1100 \mathrm{~m}$ (close to the LGM grounding line), whereas that of the upper segment remained virtually unchanged (Priestley and Reeves Glaciers) or showed a modest thickening (100-200 m) in upper Rennick Glacier (Orombelli and others, 1991; Meneghel and others, 1999). The extensive presence of meteorites in the Frontier Mountain blue-ice-field area and their terrestrial ages, attributed to the presence of blue-ice meteorite traps during full glacial times (Delisle and others, 1989; Folco and others, 2002), suggest that a moderate change in elevation occurred. Reconstructions indicate that Talos Dome was not overrun by East Antarctic ice during the LGM, and that the elevations of the dome summit and west ice saddle were probably not very different from present elevations (Kellogg and others, 1996; Denton and Hughes, 2000). The modest thickening of northern Rennick Glacier (100-200 m) with respect to the unchanged elevation of the southern glaciers (Priestley and Reeves Glaciers) suggests that the dome summit migrated southward during the LGM.

The close-off depth is $66 \mathrm{~m}$, and the ice (in the 1996 core) dates to AD 1460, with $\Delta$ ages of about 535 years. The ice thickness is expected to be $1900 \mathrm{~m}$ at the summit (TDS) and $1550 \mathrm{~m}$ at the ice divide (ID1). The age profile suggests that a core drilled at Talos Dome about $100 \mathrm{~m}$ above the bedrock could cover one glacial-interglacial period; at this depth, the 10 year resolution layer thickness would be reduced to about $6-12 \mathrm{~mm}$ of ice by dynamical strain in the ice. There was a discrepancy of about 3-4\% between calculated and measured ice ages at $89 \mathrm{~m}$ depth. The age vs depth model predicts that the transition from the Holocene to the LGM occurs at about $1200 \mathrm{~m}$ depth at the dome summit and at $880 \mathrm{~m}$ depth at the ice divide. However, given the approximations in the age model and uncertainties in the assumed climate history, a more sophisticated treatment is not justified until a new radio-echo sounding (RES) survey is completed. The average firn temperature is about $-41^{\circ} \mathrm{C}$, and the ice temperature at bedrock is expected to be around $-20^{\circ} \mathrm{C}$; basal melting has never occurred.

An explosive volcanic event that was identified in the TD core as both abundant airborne particulate matter and prominent sulphate fallout has been characterized by chemical analysis on tephra and related ice (Narcisi and others, 2001). Talos Dome drains into the blue-ice field of the Outback Nunataks, $40 \mathrm{~km}$ away. This blue-ice field contains ice from Talos Dome and also abundant tephra layers from the Mount Melbourne Volcanic Province (Perchiazzi and others, 1999). The stratigraphy and morphology of many englacial tephra layers suggests that they were deposited on snow at the time of volcanic eruption, and were incorporated into the ice with little reworking or mixing. They dip from near-horizontal to near-vertical, depending on the geometry of the local surface ice flow (Folco and others, 2002). By comparing the chemical signatures of the tephra layers, it is possible to establish reliable stratigraphic correlations between blue-ice fields and deep ice cores at Talos Dome. Old ice is known to outcrop at the surface of blue-ice areas, where it is possible to collect large volumes of ice for detailed analysis of the trace-element and gas isotopic composition. 


\section{CONCLUSIONS}

Analysis of the velocity field and surface topography shows that the surface flow centre is nearly co-located with the dome summit. In order to accurately determine the growth or shrinkage of the dome, a submergence velocity system (Hamilton and others, 1998) was installed in 2002 and measured using GPS at the TDC core, with marker embedded $54 \mathrm{~m}$ deep in firn (density $780 \mathrm{~kg} \mathrm{~m}^{-3}$ ).

The Talos Dome summit $\left(72^{\circ} 47^{\prime} 14^{\prime \prime} \mathrm{S}, 159^{\circ} 04^{\prime} 21^{\prime \prime} \mathrm{E}\right.$; $2318.5 \mathrm{~m}$ ) is situated above a sloped bedrock about $400 \mathrm{~m}$ in elevation, covered by about $1900 \mathrm{~m}$ of ice. There is a relatively flat bedrock $5-6 \mathrm{~km}$ away, along the southeast ice divide (ID1; $72^{\circ} 49^{\prime} 40^{\prime \prime} \mathrm{S}, 159^{\circ} 11^{\prime} 00^{\prime \prime} \mathrm{E}$ ), where the bedrock is about $750 \mathrm{~m}$ (WGS84) in elevation and covered by $1550 \mathrm{~m}$ of ice.

Snow radar and GPS surveys show that the internal layering is continuous and horizontal up to $15 \mathrm{~km}$ from the summit. The depth distribution analysis of snow radar layers reveals that accumulation distribution is correlated to the slope in the prevalent wind direction; snow accumulation decreases downwind of the dome (north-northeast) and increases upwind (south-southwest). The palaeomorphology of the dome has changed during the past 500 years, probably due to variation in spatial distribution of snow accumulation, driven by wind sublimation.

In order to calculate a preliminary age vs depth profile for Talos Dome, a simple one-dimensional steady-state model was formulated; this model predicts that the ice $100 \mathrm{~m}$ above the bedrock may cover one glacial-interglacial period.

Core temperature, snow accumulation and isotopicchemical snow composition (Stenni and others, 2002; Becagli and others, 2005; Magand and others, 2005) demonstrate that the climatic signal is incorporated into the firn at Talos Dome, which represents the junction of three different environments (East Antarctica-Ross Sea sector, northern Victoria Land and Wilkes Land-Southern Ocean).

Deep drilling at Talos Dome may improve our knowledge of the response of near-coastal sites to climate changes, and of Holocene accumulation rates in the Ross Sea region. It would provide detailed Holocene records of temperature, accumulation rates, trace-gas changes and aerosol variations with respect to other Antarctic sites. As such, it would make a significant contribution to future drilling networks focusing on the spatial distribution of key tracers in Antarctica (complementing studies at EPICA-DML, Berkner Island, Inland US core, etc.). In addition, Talos Dome would strongly contribute to the understanding of the last glacialinterglacial transition, when different climatic features and trends are observed in East Antarctica, Taylor Dome, Siple Dome and Law Dome.

Several studies are in progress to improve our knowledge of the Talos Dome area and identify a deep-drilling site. A stake farm (40 poles) was installed in 2002, and an automatic weather station was installed during the 2002/ 03 season in order to characterize climatic conditions and the spatial-temporal variability of snow precipitation on local and seasonal scales. A new RES and snow radar survey will be performed in the dome area during the 2003/04 season to survey internal layering, snow accumulation variability, large-scale flow disturbances and detailed bedrock topography. The new survey will be used to test the accuracy of ice-flow models, calculate the age of ice at the summit or along the ice divide, and survey the pattern of buried former ice-sheet surfaces below the dome.

\section{ACKNOWLEDGEMENTS}

Research was carried out within the framework of a Project on Glaciology of the Programma Nazionale di Ricerche in Antartide (PNRA) and was financially supported by Ente per le Nuove tecnologie, I'Energia e l'Ambiente (ENEA) through a cooperation agreement with the Università degli Studi di Milano Bicocca. This work is an Italian contribution to the ITASE project.

\section{REFERENCES}

Becagli, S. and 12 others. 2004. Chemical and isotopic snow variability in East Antarctica along the 2001/02 ITASE traverse. Ann. Glaciol., 39 (see paper in this volume).

Dansgaard, W. and S. J. Johnsen. 1969. A flow model and a time scale for the ice core from Camp Century, Greenland. J. Glaciol., 8(53), 215-223.

Delisle, G. and 11 others. 1989. Meteorite finds near the Frontier Mountain Range in north Victoria Land. Geol. Jahrb., Ser. E, 38, 483-513.

Delmonte, B., J.-R. Petit and V. Maggi. 2002. Glacial to Holocene implications of the new 27000-year dust record from the EPICA Dome C (East Antarctica) ice core. Climate Dyn., 18(8), 647-660. (10.1007/s00382-001-0193-9.)

Denton, G. H. and T. J. Hughes. 2000. Reconstruction of the Ross ice drainage system, Antarctica, at the Last Glacial Maximum. Geogr. Ann., 82A(2-3), 143-166.

Deponti, A. and V. Maggi. 2003. Talos Dome age vs. depth modelling. Terra Antarct. Rep., 8, 113-116.

Drewry, D. J. 1983. Antarctica: glaciological and geophysical folio. Cambridge, University of Cambridge. Scott Polar Research Institute.

Folco, L., A. Capra, M. Chiappini, M. Frezzotti, M. Mellini and I. E. Tabacco. 2002. The Frontier Mountain meteorite trap (Antarctica). Meteoritics Planet. Sci., 37(2), 209-228.

Frezzotti, M. and O. Flora. 2002. Ice dynamic features and climatic surface parameters in East Antarctica from Terra Nova Bay to Talos Dome and Dome C: ITASE Italian traverses. Terra Antartica, 9(1), 47-54.

Frezzotti, M., O. Flora and S. Urbini. 1998. The Italian ITASE expedition from Terra Nova station to Talos Dome. Terra Antartica Reports, 2, 105-108.

Frezzotti, M., S. Gandolfi, F. La Marca and S. Urbini. 2002a. Snow dunes and glazed surfaces in Antarctica: new field and remotesensing data. Ann. Glaciol., 34, 81-88.

Frezzotti, M., S. Gandolfi and S. Urbini. 2002b. Snow megadunes in Antarctica: sedimentary structure and genesis. J. Geophys. Res., 107(D18), 4344. (10.1029/2001JD000673.)

Frezzotti, M. and 7 others. 2003. Geophysical survey at Talos Dome (East Antarctica). Terra Antartica Reports, 8, 117-120.

Frezzotti, M. and 13 others. 2004. New estimations of precipitation and surface sublimation in East Antarctica from snow accumulation measurements. Climate Dyn, 23(7-8), 803-813. (10.1007/s00382-004-0462-5.)

Frezzotti, M. and 13 others. 2005. Spatial and temporal variability of snow accumulation in East Antarctica from traverse data. J. Glaciol., 172, in press.

Hamilton, G. S., I. M. Whillans and P. J. Morgan. 1998. First point measurements of ice-sheet thickness change in Antarctica. Ann. Glaciol., 27, 125-129.

Huybrechts, P. 2002. Sea-level changes at the LGM from icedynamic reconstructions of the Greenland and Antarctic ice sheets during the glacial cycles. Quat. Sci. Rev., 21(1-3), 203-231. 
Kellogg, T. B., T. Hughes and D. E. Kellogg. 1996. Late Pleistocene interactions of East and West Antarctic ice-flow regimes: evidence from the McMurdo Ice Shelf. J. Glaciol., 42(142), 486-500.

Kobayashi, S. and T. Ishida. 1979. Interaction between wind and snow surface. Boundary-Layer Meteorol., 16, 35-47.

Loewe, F. 1970. Screen temperatures and $10 \mathrm{~m}$ temperatures. J. Glaciol., 9(56), 263-268.

Lythe, M. B., D. G. Vaughan and BEDMAP consortium. 2000. BEDMAP-bed topography of the Antarctic. (Scale $1: 10,000,000$.) British Antarctic Survey. (BAS (Misc) 9, http:// www.antarctica.ac.uk/aedc/bedmap/.)

Magand, O., M. Frezzotti, M. Pourchet, B. Stenni, L. Genoni and M. Fily. 2004. Climate variability along latitudinal and longitudinal transects in East Antarctica. Ann. Glaciol., 39, (see paper in this volume)

Mancini, M. and M. Frezzotti. 2003. Surface wind field along ITITASE traverse (East Antarctica). Terra Antartica Reports, 8, 57-59.

Meneghel, M., A. Bondesan, M. C. Salvatore and G. Orombelli. 1999. A model of the glacial retreat of upper Rennick Glacier, Victoria Land, Antarctica. Ann. Glaciol., 29, 225-230.

Morgan, V. and 7 others. 2002. Relative timing of deglacial climate events in Antarctica and Greenland. Science, 297(5588), 1862 1864.

Narcisi, B., M. Proposito and M. Frezzotti. 2001. Ice record of a 13th century explosive volcanic eruption in northern Victoria Land (East Antarctica). Antarct. Sci., 13(2), 174-181.

Orombelli, G., C. Baroni and G. H. Denton. 1991. Late Cenozoic glacial history of the Terra Nova Bay region, northern Victoria Land, Antarctica. Geogr. Fís. Din. Quat., 13(2), [1990], 139-163.

Parish, T.R. and D. H. Bromwich. 1991. Continental-scale simulation of the Antarctic katabatic wind regime. J. Climate, $\mathbf{4}(2)$, 135-146.

Perchiazzi, N., L. Folco and M. Mellini. 1999. Volcanic ash bands in the Frontier Mountain and Lichen Hills blue-ice fields, northern Victoria Land. Antarct. Sci., 11(3), 353-361.

Petit, J.-R. and 18 others. 1999. Climate and atmospheric history of the past 420,000 years from the Vostok ice core, Antarctica. Nature, 399(6735), 429-436.

Reeh, N. 1989. Dating by ice flow modeling: a useful tool or an exercise in applied mathematics? In Oeschger, $\mathrm{H}$. and C.C. Langway Jr, eds. The environmental record in glaciers and ice sheets. Chichester, etc., John Wiley and Sons, 141-159.

Rémy, F., P. Shaeffer and B. Legrésy. 1999. Ice flow physical processes derived from ERS-1 high-resolution map of Antarctica and Greenland ice sheet. Geophys. J. Int., 139(3), 645-656.

Richardson, C. and P. Holmlund. 1999. Spatial variability at shallow snow-layer depths in central Dronning Maud Land, East Antarctica. Ann. Glaciol., 29, 10-16.

Richardson, C., E. Aarholt, S.-E. Hamran, P. Holmlund and E. Isaksson. 1997. Spatial distribution of snow in western Dronning Maud Land, East Antarctica, mapped by a groundbased snow radar. J. Geophys. Res., 102(B9), 20,343-20,353.

Ritz, C., V. Rommelaere and C. Dumas. 2001. Modeling the evolution of Antarctic ice sheet over the last 420,000 years: implications for the altitude changes in the Vostok region. J. Geophys. Res., 106(D23), 31,943-31,964.

Robin, G. deQ. 1983. Ice sheets: isotopes and temperatures. In Robin, G. de Q., ed. The climatic record in polar ice sheets. Cambridge, Cambridge University Press, 1-18.

Schwander, J., J. Jouzel, C. U. Hammer, J.R. Petit, R. Udisti and E. Wolff. 2001. A tentative chronology for the EPICA Dome Concordia ice core. Geophys. Res. Lett., 28(22), 4243-4246.

Stenni, B. and 6 others. 2000. Snow accumulation rates in northern Victoria Land, Antarctica, by firn-core analysis. J. Glaciol., 46(155), 541-552.

Stenni, B. and 6 others. 2002. Eight centuries of volcanic signal and climate change at Talos Dome (East Antarctica). J. Geophys. Res., 107(D9), 4076. (10.1029/2000JD000317.)

Stuart, A.W. and A.J. Heine. 1961. Glaciological work of the 1959-60 US Victoria Land traverse. J. Glaciol., 3(30), 9971002.

Tabacco, I.E., A. Passerini, F. Corbelli and M. Gorman. 1998. Correspondence. Determination of the surface and bed topography at Dome C, East Antarctica. J. Glaciol., 44(146), 185-191.

Tabacco, I. E., C. Bianchi, A. Zirizzotti, E. Zuccheretti, A. Forieri and A. Della Vedova. 2002. Airborne radar survey above Vostok region, east-central Antarctica: ice thickness and Lake Vostok geometry. J. Glaciol., 48(160), 62-69.

Urbini, S., S. Gandolfi and L. Vittuari. 2001. GPR and GPS data integration: examples of application in Antarctica. Ann. Geofis., 44(4), 687-702.

US Geological Survey. 1970. Welcome Mountain, Antarctica. 1:250,000. (Reconnaissance Series, SS 55-57/4) Washington, DC, United States Geological Survey.

Van der Veen, C. J. and I. M. Whillans. 1992. Determination of a flow center on an ice cap. J. Glaciol., 38(130), 412-416.

Vaughan, D. G., H. F. J. Corr, C. S. M. Doake and E. D. Waddington. 1999. Distortion of isochronous layers in ice revealed by ground-penetrating radar. Nature, 398(6725), 323-326.

Warner, R.C. and W. F. Budd. 1998. Modelling the long-term response of the Antarctic ice sheet to global warming. Ann. Glaciol., 27, 161-168.

Watanabe, O., J. Jouzel, S. Johnsen, F. Parrenin, H. Shoji and N. Yoshida. 2003. Homogeneous climate variability across East Antarctica over the past three glacial cycles. Nature, 422(6931), 509-512. 